\title{
A Needs Analysis of Mothers from Multicultural Family for Child Language Development Screening Tests: Using Focus Group Interview
}

\author{
Eun Jung Choi ${ }^{a}$, Sang-Im Jung ${ }^{\mathrm{b}}$, Dongsun Yim ${ }^{\mathrm{a}}$, Young Tae Kim ${ }^{\mathrm{a}}$ \\ ${ }^{a}$ Department of Communication Disorders, Ewha Womans University, Seoul, Korea \\ ${ }^{b}$ Department of Speech-Language Therapy \& Aural Rehabilitation, Woosong University, Daejeon, Korea
}

Correspondence: Dongsun Yim, PhD Department of Communication Disorders, Ewha Womans University, 52 Ewhayeodae-gil, Seodamun-gu, Seoul 03760, Korea

Tel: $+82-2-3277-6720$

Fax: +82-2-3277-2122

E-mail: sunyim@ewha.ac.kr

Received: April 5, 2019

Revised: May 13, 2019

Accepted: May 13, 2019

This work was supported by the Ministry of Education of the Republic of Korea and the National Research Foundation of Korea (No. NRF-2018S1A3A2075274)

\begin{abstract}
Objectives: Children from multicultural families tend to have issues with various areas of language development. As such, it is important to do early screening of the language development of children from multicultural families to determine their level of development. To this end, language development screening tests that reflect the special nature of multicultural families should be designed. There is a need for qualitative research because quantitative research alone cannot reflect the real needs of people from multicultural families. In accordance with this need, this study sought to analyze the perceptions and needs of mothers of multicultural families to assist in language development screening for children. Methods: Eleven mothers of multicultural families were chosen to participate in the study and were divided into two groups. The researcher conducted a Focus Group Interview (FGI) and then analyzed the results. Results: The results of the interview were analyzed and categorized based on three main topics (results from the experience of language development test, difficulty in assessing the child's language development, and demand for improvement of the language development test) and nine subtopics. Conclusion: In order to develop a language development screening test for children from multicultural families, consideration needs to be given to language barriers, language development information, and the language development test.
\end{abstract}

Keywords: Multicultural family, Language screening test, Qualitative research, Focus Group Interview, Needs analysis
넓은 의미에서 다문화가정은 국제결혼에 따른 이주 여성, 외국인 노동자, 그리고 탈북자 출신의 새터민 등으로 한국사회 내에 남한 이 아닌 다른 문화권으로 이루어진 가정을 의미한다(Suh, 2007) 하지만 연구자의 연구목적에 따라 협의개념이 혼용되어서도 적용 되고 있는데, 다문화가족지원법에 근거한 다문화가정은 결혼 이민 자 또는 귀화자와 한국인으로 이루어진 좁은 의미의 다문화가정, 국제결혼가족으로 한정된다(Kim, 2015). 행정안전부의 통계에 따 르면 2017년 기준으로 다문화가구의 가구원은 총 963,801 명, 자녀 의 수는 220,950명으로 꾸준한 증가 추세에 있다(Ministry of Interior and Safety, 2018). 이처럼 국내 다문화가정 자녀의 수가 증가함 에 따라 다문화가정 아동의 발달에 대한 관심 역시 증가하고 있으
며, 특히 언어병리학 분야에서는 이 집단 아동들의 언어발달에 관 한 다양한 연구가 진행되고 있다.

일반적으로 많은 연구진들은 집단 간 비교를 통한 다문화 아동 과 일반 또래아동의 언어발달 수준을 분석하였다(Ahn \& Shin, 2008; Hwang \& Jeong, 2008; Kim, Kim, \& Lee, 2007; Kwon, 2006; Lee, Shin, Kim, \& Kim, 2008; Park, 2009; Yang \& Hwang, 2009; Yoo, Kim, Kim, \& Shin, 2008). 이러한 연구결과들을 통해 다문화 아동이 음운, 의미, 문법, 읽기 등의 다양한 영역에서 또래아동에 비해 낮은 수행능력을 보인다는 것을 알 수 있었으며, 대다수의 학 령전기 다문화 아동들이 표준화 검사에서 언어발달 지체를 보이는 것으로 나타났다(Lee et al., 2008; Oh, Kim, \& Kim, 2009). 이러한 
맥락에서 위험군에 있는 다문화 아동의 언어발달을 위한 효과적인 지원이 필요하며, 이를 위해 다문화 아동의 언어발달 수준을 영유 아기에 조기 선별하는 선행적 과정이 매우 중요하다. 영유아기는 언 어발달의 양상을 예측할 수 있는 중요한 시기로 생애 첫 5-7년은 언 어발달의 결정적 시기이며(Pence \& Justice, 2008), 영유아기의 언어 발달 문제들은 아동이 성장하면서 더욱 심한 언어장애로 발전할 가능성이 높다(Olswang, Rodriguez, \& Timler, 1998).

하지만 다문화 아동의 조기 선별을 위해서는 더 많은 양적 및 질 적 연구가 필요한 실정이다. 대부분의 연구에서 다문화 아동의 언 어 수행능력을 측정하는 데에 사용한 공식검사는 한국 아동을 대 상으로 표준화된 검사도구들인데, 이러한 검사도구들의 내용에는 다문화 아동의 언어 및 문화적인 배경이 전혀 반영되어 있지 않기 때문에 그 결과를 모두 신뢰하기 어렵다. 또한 우리나라 다문화가 정 아동은 다른 나라의 경우와는 달리 주로 국제결혼을 통해 이주 한 어머니의 특성을 반영하기 때문에 검사 개발 과정에 이점을 고 려할 필요가 있다. 그 특성 중 하나로 다문화가정의 어머니들은 자 녀와의 상호작용 상황에서 자신의 모국어보다는 한국어를 사용하 는 경우가 많은데, 어머니의 서툰 한국어는 아동 언어발달에 필요 한 적절한 자극의 양적 및 질적인 결핍을 초래한다(Oh et al., 2009). 다문화가정 어머니들의 한국어 능력과 자녀의 언어능력에 대한 정 적인 상관관계는 여러 선행연구를 통해 보고되었으며(Hwang \& Jeong, 2008; Lee et al., 2008), 어머니의 낮은 한국어 능력은 아동의 언어발달에 대한 어머니의 인식이나 민감도, 그리고 아동 평가에 중요한 부분을 차지하는 주양육자의 보고의 질에도 부정적인 영향 을 미칠 것이라고 예상할 수 있다. 따라서 다문화 아동의 언어발달 을 더 정확하게 평가하기 위해서는 다문화가정의 특수성에 대한 질 적인 탐구와 고려를 통해 더 타당하고 접근성 있는 평가방법을 고 안할 필요가 있다.

다문화 아동의 언어평가를 어렵게 하는 요인에는 평가방법 자체 의 어려움 이전에 아동이 언어평가에 접근하기까지의 외적인 어려 움도 있는 것으로 보인다. 보건복지부 보도자료에 따르면 다문화가 정 아동들의 영유아 건강검진 수검률은 2008년 27.3\%와 2009년 $36.0 \%$ 로 전국 영유아 건강검진 수검률 36.5\% (2008년), $40 \%$ (2009 년)보다 낮게 집계되었다(Ministry of Health and Welfare, 2010). 검진의 특성상 검사보다 영유아의 성장발달에 대한 전문가와의 상 담이 주된 절차이기 때문에 보호자의 한국어가 능숙하지 않을 경 우 형식적인 검진에 머물거나 아예 검진을 받지 못하는 경우가 많 은 것으로 조사되었다.

한편 앞서 언급된 연구들을 포함한 대부분의 연구들이 다문화 아동의 언어능력과 발달에 대한 양상을 탐구하기 위해 양적 비교
연구방법을 사용하였고, 이에 반해 다문화 아동의 언어에 관한 질 적 연구는 다문화가정 자녀의 국어사용실태(Kwon, 2009), 다문화 가정 아동의 언어치료에 대한 질적 연구(Park \& Jung, 2012) 등 소 수의 연구만이 이루어졌다. 양적 연구를 통해서 다문화가정 아동 의 언어 발달에 관한 객관적 자료를 얻을 수는 있지만, 다문화가정 이라는 특수한 대상자들이 경험하는 실제적 어려움과 요구 등을 파악하기 어렵다는 점에서 다각적이고 심층적인 정보에 대한 질적 연구방법이 시급히 필요하다.

이러한 필요에 따라 본 연구에서는 포커스 그룹 인터뷰(Focus Group Interview, FGI)를 진행하여, 다문화 아동의 언어발달에 새 롭게 접근해 보고자 하였다. FGI는 특정 주제에 대해 6-8명의 참여 자들이 만나서 함께 이야기를 나누는 방식으로 전개되는 조사방법 이다. 숙련된 진행자(moderator)의 주도하에 비구조적인 접근법을 사용하여 참여자들이 자유롭게 토론하도록 진행하며, 모든 참여 자들의 반응을 통합하여 가설의 추출과 검증 등의 목적으로 활용 된다. 특히 규모가 큰 연구에서 초기에 선행연구의 한 방법으로 사 람들 간의 의사소통이 어렵거나 이해의 벽이 있을 때, 복잡한 행동 이나 동기를 밝힐 때, 새로운 관점이나 창의력이 요구될 때, 제품 개 념의 방향을 찾거나 소비자의 생각을 직접 접하고 싶을 때 유용한 연구방법이다(Cho, Lee, Joo, \& Kim, 2011).

본 연구는 다문화가정의 어머니들을 대상으로 자녀의 언어발달 및 평가에 대한 인식을 포커스 그룹 인터뷰(FGI)를 통하여 살펴보 고, 이를 통해 다문화가정 아동의 배경을 고려한 언어발달 검사 개 발의 기초를 마련하는 것을 목적으로 하였다. 이러한 연구목적을 달성하기 위하여 설정한 연구문제는 다음과 같다.

첫째, 다문화가정 어머니들의 영유아 언어발달검사 수검 경험과 인식은 어떠한가?

둘째, 다문화가정 어머니들의 영유아 언어발달검사 개선 요구 및 기대는 어떠한가?

\section{연구방법}

본 연구는 반구조화된 면담을 통해 다문화가정의 어머니들의 영 유아 언어발달검사에 대한 실질적인 경험과 인식을 이해하고, 구체 적인 개선 요구 및 기대를 알아보고자 하였다. 이를 위해 사용된 연 구절차는 다음과 같다.

\section{연구 참여자}

본 연구는 한국인과의 결혼으로 인해 구성된 다문화가정의 어머 니 11명을 대상으로 하였다. 연구 참여자는 (1) 서울지역에 거주하 
Table 1. Participants' characteristics

\begin{tabular}{llccccc}
\hline Group & ID & $\begin{array}{c}\text { Age } \\
\text { (yr) }\end{array}$ & $\begin{array}{c}\text { Country of } \\
\text { origin }\end{array}$ & $\begin{array}{c}\text { Educa- } \\
\text { tion (yr) }\end{array}$ & $\begin{array}{c}\text { Duration of } \\
\text { residence in } \\
\text { Korea (yr;mo) }\end{array}$ & $\begin{array}{c}\text { Age of } \\
\text { child } \\
\text { (yr;mo) }\end{array}$ \\
\hline Group 1 & Participant 1 & 34 & Vietnam & 12 & $2 ; 8$ & $1 ; 7$ \\
& Participant 2 & 29 & Vietnam & 16 & $2 ; 4$ & $1 ; 7$ \\
& Participant 3 & 28 & Vietnam & 16 & $3 ; 9$ & $3 ; 5$ \\
& Participant 4 & 32 & Cambodia & 16 & $7 ; 9$ & $7 ; 1$ \\
& Participant 5 & 34 & Philippines & 16 & $9 ; 11$ & $7 ; 3$ \\
Group 2 & Participant 6 & 28 & Philippines & 12 & $2 ; 9$ & $2 ; 0$ \\
& Participant 7 & 32 & Cambodia & 12 & $2 ; 9$ & $6 ; 6$ \\
& Participant 8 & 33 & Vietnam & 5 & $4 ; 6$ & $2 ; 6$ \\
& Participant 9 & 29 & Vietnam & 5 & $3 ; 4$ & $2 ; 4$ \\
& Participant 10 & 27 & Vietnam & 12 & $3 ; 10$ & $2 ; 10$ \\
& Participant 11 & 31 & Vietnam & 12 & $7 ; 10$ & $6 ; 0$ \\
\hline
\end{tabular}

고, (2) 학령전기의 자녀를 두었으며, (3) 다문화가족지원센터의 이 중언어 발달지도사의 확인을 거쳐 일상적 한국어 대화가 가능한 어머니들로 선정하였다. 인터뷰참여자의 기본 정보는 Table 1과 같다.

\section{자료수집 절차}

\section{인터뷰 질문 구성}

인터뷰 질문은 타당도 검증을 위해 두 명의 연구자들이 선행연 구들을 검토하고 의견을 조율하여 구성하였다. 질문의 주요 주제 는 (1) 영유아 언어발달 선별검사의 수검 경험, (2) 자녀 언어발달에 대한 평가, 그리고 (3) 개선 및 지원 요구였다. 질문은 반구조화된 개 방형으로 참여자들에게 연구자가 구어로 제시하였으며, 전체적인 주제의 구성은 Table 2 와 같다. 다문화가정 어머니들이 질문을 잘 이해할 수 있을지 판단하기 위해, 다문화가족지원센터에서 5년 이 상 근무한 1 급 언어재활사에게 자문을 구하였다. 또한 질적 연구 전 문가 1 인과 언어병리학 박사과정 2 인이 문항별 5점척도를 사용하 여 타당도를 평가하였고, 평가자들의 문항타당도 평균점수가 3.5 이상으로 확인된 문항만을 선별하여 인터뷰 질문으로 활용하였다.

\section{인터뷰 실시 및 자료 전사}

본 인터뷰는 참여자들에게 충분한 발화 기회를 부여하고, 참여 자들 간의 원활한 상호작용이 이루어지도록 각각 5 명과 6 명으로 구성된 두 개의 그룹으로 진행하였다. 참여자들의 출신 국가가 특 정 국가에 치중되지 않도록 각 그룹을 구성하였으며, 인터뷰 이전 에 연구의 목적과 방법에 대한 충분한 설명 후 동의서를 작성하도 록 하였다.

인터뷰 과정에는 두 명의 연구자가 참여하였으며, 한 명은 중재 자(moderator) 역할을 하여 질문을 제시하고, 토론을 진행하였다.
Table 2. Discussion topics

\begin{tabular}{|c|c|}
\hline Theme & Related discussion topics \\
\hline $\begin{array}{l}\text { Experience of language developm } \\
\text { screening tests for children }\end{array}$ & $\begin{array}{l}\text { Type of tests } \\
\text { Impression about experience }\end{array}$ \\
\hline $\begin{array}{l}\text { Evaluation of children's language } \\
\text { development }\end{array}$ & $\begin{array}{l}\text { Accessibility to language development tests } \\
\text { Difficulties in self evaluation }\end{array}$ \\
\hline $\begin{array}{l}\text { Demand for improvement and } \\
\text { support }\end{array}$ & $\begin{array}{l}\text { Suggestions } \\
\text { Needs of support }\end{array}$ \\
\hline
\end{tabular}

참여자들이 최대한 자유롭게 의견을 제시하도록 하였으며, 참여자 의 반응이 모호하거나 불충분할 경우 추가적인 질문을 통해 참여 자의 구체적인 응답을 이끌어내고자 하였다. 또 다른 한 명의 연구 자는 인터뷰 상황에 대한 현장 노트를 작성하고, 모든 참여자에게 균등한 발언의 기회가 부여되도록 발언 횟수를 체크하여 인터뷰 진행에 도움을 제공하였다.

기존의 언어발달검사에 대해 친숙하지 않은 참여자가 대부분이 었고, 더 구체적인 개선안 및 요구사항을 제시할 수 있도록 임상에 서 널리 사용되고 있는 영유아 언어발달검사(Sequenced Language Scale for Infants, SELSI; Kim, Kim, Yoon, \& Kim, 2003)의 검사지 를 배부하였다. 참여자들은 검사지를 천천히 살펴보고 검사 문항 의 이해 정도, 개선 및 요구안을 자유롭게 제시하도록 하였다.

인터뷰 참여자는 일상적인 한국어 대화가 가능한 수준으로 선 정하였으나, 한국 거주기간이 최소 2년 4개월에서 9년 11개월로 다 양하였고, 이에 따라 한국어 수준도 개인별 차이가 나타났다. 따라 서 토론 주제에 따라 일부 참여자는 검사자의 질문을 정확히 이해 하기 어려워하거나, 자신의 의견을 충분히 표현하는 데 한계가 있었 고, 이러한 경우 한국어가 유창한 다른 참여자들이 통역을 해 주거 나, 영어로 소통하는 방식으로 보완하여 진행하였다.

인터뷰는 서울 시내의 다문화가족지원센터의 조용한 강의실에 서 이루어졌으며, 연구자와 참여자들은 서로의 얼굴을 볼 수 있도 록 V자 형태로 책상과 의자를 배치하였다. 인터뷰의 모든 내용은 참여자 동의하에 녹화 및 녹음이 동시에 진행되었으며, 소요시간 은 그룹별로 100-120분이었다.

\section{자료 분석}

두 명의 연구자는 모든 인터뷰의 내용을 진행자와 참여자의 진 술을 포함하여 전사하였다. 연구자는 인터뷰 영상과 녹음본을 반 복하여 확인하며, 참여자가 보인 행동이나 표정 등의 비언어적인 표현도 발화와 구분하여 전사본에 기입하였고, 전사 자료는 $\mathrm{A} 4$ 용 지로 총 58 페이지(글자크기 10 , 줄간격 1.8) 분량이었다. 이를 통해 얻어진 자료는 지속적 비교법(constant comparative method)을 이 용하여 분석하였다(Strauss \& Corbin, 1990). 연구자는 인터뷰 내 


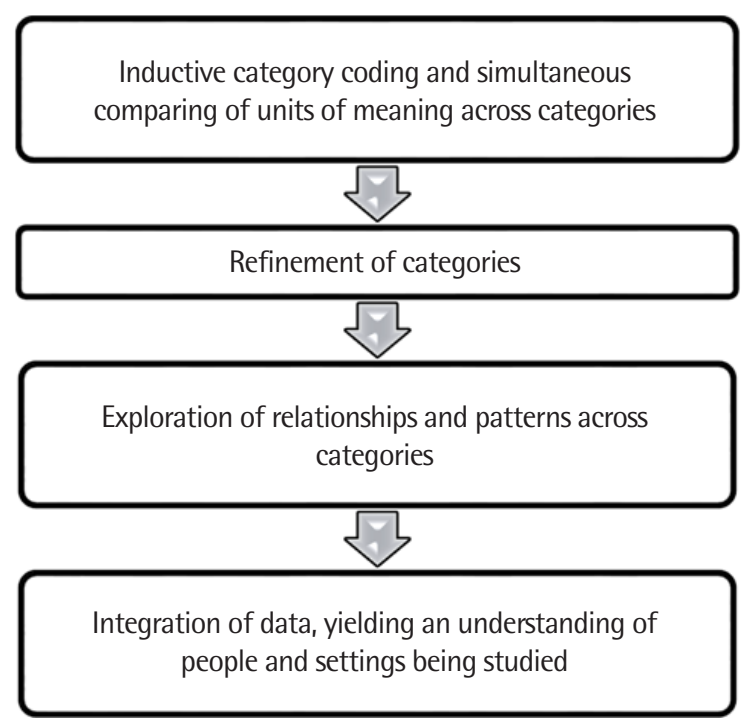

Figure 1. Steps in the constant comparative method. Adapted from "Peer teaching in web based threaded discussions," by by W. F. Brescia, J. Swartz, C. Pearman, R. Balkin, \& D. Williams, 2004, Journal of Interactive Online Learning, 3(2), p. 5.

용을 파악하기 위해 전사본 전체를 반복적으로 읽어보며 코드를 작성하였고, 첫 번째 작성한 코드에 따라 발화를 분석하면서 새롭 게 나타난 주제를 기록해 나가며 추가적 코드를 만들어내는 개방 적 코딩 절차를 따라 자료를 분석하였다(Bogdan \& Biklen, 2007). 이 과정을 통해 코드를 재범주화하여 최종적으로 3 가지의 대주제 와 9 개의 하위주제를 도출하였다. 이상의 분석 과정을 도식으로 표 현하면 Figure 1과 같다(Brescia, Swartz, Pearman, Balkin, \& Williams, 2004).

\section{신뢰도(credibility) 확보를 위한 노력}

질적 연구에서의 신뢰도(credibility)란 사회적 상황 안에서 연구 참여자가 경험한 내용과 연구자에 의해 서술되고 묘사된 내용 간 의 일치 정도를 의미한다(Schwandt, 2014). 연구자들은 본 연구의 신뢰도 확보를 위해 녹화 및 녹음 자료와 전사본을 반복 확인하여 분석하였다. 또한 인터뷰 자료에 대한 하나 이상의 관점을 얻기 위 해서 삼각측량법(triangulation)을 사용하였고, 세 명의 리뷰어가 분석을 진행하였다. 모든 리뷰어들은 토론을 통해 의견을 주고받 았으며, 주요 주제(major themes)와 하위주제(sub-themes)에 대해 구두로 합의에 도달하였다.

\section{연구결과}

인터뷰를 통해 수집한 자료를 질적 분석한 결과, 다음과 같은 3
Table 3. Major and sub-themes drawn from data

\begin{tabular}{ll}
\hline Major theme & \multicolumn{1}{c}{ Sub-theme } \\
\hline $\begin{array}{l}\text { Experience of language develop- } \\
\text { ment screening tests for chil- } \\
\text { dren }\end{array}$ & $\begin{array}{l}\text { Test types and institutions } \\
\text { Reason for test request and approach path } \\
\text { Subjective evaluation of the language devel- } \\
\text { opment assessment }\end{array}$ \\
$\begin{array}{ll}\text { Difficulty of evaluating children's } \\
\text { language development }\end{array}$ & $\begin{array}{l}\text { Language difficulty } \\
\text { Lack of information } \\
\text { Lack of support }\end{array}$ \\
Demands for improvement & $\begin{array}{l}\text { Increasing channels for providing information } \\
\text { Support for language difficulties } \\
\text { Enhancing accessibility and usability }\end{array}$ \\
\hline
\end{tabular}

개의 대주제가 도출되었고 총 9 개의 하위주제가 도출되었다. 도출 된 대주제는 (1) 언어발달 수검 경험, (2) 자녀 언어발달 평가의 어려 움 및 대처방법, (3) 언어발달검사에 대한 개선 요구이고 하위주제 들 간의 관계는 Table 3에 제시하였다.

\section{언어발달검사 수검 경험}

언어발달검사 수검 여부와 관련 검사의 유형에 대한 질문에 연 구 참여자들은 대부분 소아과에서 기본적으로 받은 영유아 발달 선별검사를 언급하였다. 소아과에서 준 간단한 체크리스트를 작성 하거나, 의사나 간호사의 질문에 대답하는 형식으로 검사를 시행 하였음을 알 수 있었다. 이외에는 특별히 자녀의 언어발달검사의 필요성을 느낀 적이 없었다는 대답이 대부분이었고, 아동의 언어 발달이 또래보다 늦거나 발달 지체가 걱정되어 따로 검사를 받아본 참여자가 각각 한 명씩 있었다. 그들은 다문화센터와 사설 언어치 료실을 방문하여 자녀의 언어발달검사를 받았는데, 구체적인 검사 명이나 내용을 기억하는 것은 어려워했다.

“건강검진(영유아건강검진) 매년 받습니다.” (참여자 10)

"바로 $O O$ 아동발달센터 가서 바로 언어 검진하고, 치료 바로 받았어요." (참여자 3 )

"여기 (다문화)센터에서 언어발달 선생님 계시잖아요. 평가 한 번 받은 적이 있거든요.” (참여자 7)

언어발달검사 계기 및 접근 경로에 대한 질문에 연구 참여자들 은 소아과에 검사의 안내를 받았다는 이야기를 가장 많이 하였고, 다문화센터 선생님의 권유를 통해서 검사를 받게 되었다는 참여자 와자녀의 언어발달이 늦는 것이 걱정되어 자발적으로 기관을 검색 해 보고 방문하여 검사를 받았다고 이야기한 참여자가 각각 한 명 씩 있었다.

\section{“병원에서 그냥 짔어요."(참여자 7)}

"다문화 선생님이 지난번에 저한테 애기 한 번 데려와, 검사 
해 줄게."(참여자 11)

“저희 동네에 애기 많거든요. 같은 나이 애기 많고, 다른 애기 보다 우리 애기 말 좀 못하잖아요. 그래서 그냥 인터넷으로. 근 처에 어떤 병원(센터) 있는지 봤어요."(참여자 3 )

자녀의 언어발달검사수검 과정 중 느낀 불만으로는 검사 과정이 꼼꼼하지 않다는 것과 검사지 작성이 어렵다는 점이 언급되었다.

"소아과 좀 그냥 대충대충해요. 그냥 뭐 꼼꼼하게 검사안 해 요. 한 번 받아서 생각하니까 너무 대충해서 소아과 별로 안 가 요. 검진하면."(참여자 3)

"근데 이걸 병원에서 검진할 때 따로 답안지 따로 있어요. 번 호 체크하고. 막 헷갈리더라고요. 보통은 3 번, 이런 거 체크해가 지고 플러스해서 점수 몇 번 나오잖아요. 답안지 따로."(참여자7)

\section{자녀 언어발달평가의 어려움}

\section{언어적 어려움}

연구 참여자들은 자녀의 언어발달을 평가하는 과정에서 경험하 는 핵심적인 어려움으로 의사소통의 어려움을 공통적으로 보고하 였다. 의사소통의 어려움의 주된 원인으로는 이들의 미숙한 한국 어 실력으로 인한 언어 장벽 문제를 지적하였다. 구체적인 어려움 을 느끼는 상황에 대한 질문에는 참여자들의 한국 거주기간과 그 에 따른 한국어 능력의 차이로 느끼는 어려움의 정도는 개인 간 차 이가 있었지만, 자녀가 다니는 교육기관의 교사나 의료기관의 전문 가들과 상담하는 데에 특히 어려움을 느낀다고 보고하였다.

"선생님 상담은 선생님 말 너무 빨리빨리 해요. 저는 stop해 요. 천천히 말해요. 너무 빠른 거 저는 못 알아들어요. 이렇게 애기해요."(참여자4)

"복잡한 애기 몰라요. (의사) 선생님이 아빠, 전화해요. 제가 몰라요."(참여자 2)

"예전엔 많이 어려웠어요. 그래서 그거 무슨 말이냐. 다시 물 어보고, 체크하기 전에 다 물어봤어요."(참여자 7)

"병원에서 어떤 선생님이 옆에 계시면서 도와주고, 이 문장 을 설명해 주잖아요. 그럼 할 수 있어요. 그냥 이거(검사지) 주 고, 알아서 하는 건 어려운 부분이 많이 있을 거예요."(참여자 7)

“어려워요. 선생님이 도와줘요. 글씨 잘 몰라요."(참여자 8)

또한, 한국어로 된 검사 안내문이나 검사지를 읽고 이해하는 데 에 어려움이 크고 피로함을 느끼며, 그로 인해서 자신감이 떨어지 거나 관심이 줄어든다는 언급도 있었다.

"내가 외국 사람이잖아요. 한국말잘 못해서 자신 없어요. 그
래서 이거(검사 안내문) 아마 저희 집 보내오면, 아 뭐야? 이해 못하는 게 아니고, 베트남말로 있으면 고향 말로 있으면 제가 읽겠죠? 하지만 다 한국, 한글로 하잖아요. 지금 뭔가, 읽을까? 안 읽을까? 다 버렸어요."(참여자3)

"글 읽을 때 제가 이해 못하는 것도 많거든요. 그래서 저는 (검사안내문에) 신경도 안 쓰고...”(참여자 10)

연구 참여자들이 실제 검사지를 작성할 때 느끼는 경험에 대해 더 자세히 알아보기 위해 영유아의 언어발달 문제의 선별 목적으 로 널리 사용되고 있는 영유아 언어발달검사(SELSI)의 검사지를 나누어 준 후 살펴보도록 하였다. 검사지에 있는 문항의 이해도와 느낌에 대해 묻는 질문에 참여자들은 이해할 수 있는 문항도 있지 만 이해할 수 없는 문항도 있다고 대답하였다. 어려운 부분으로는 질문 문항에 사용된 어휘 이해의 어려움을 언급하였는데, 특히 전 문용어나 한자어 표현 등 문어체 표현에서 이해하기에 어려운 어휘 가 많다고 지적하였다.

“아니, 다 이해 안 돼요. 조금만 알아요.”(참여자9)

“여기 28번에 다른 사람 이야기하는 동안 산만해지지 않고, '산만하다' 무슨 뜻인지 모르겠어요. 그리고 '청자와 화자 변별 하기’ 이거 무슨 뜻인지 모르겠어요. 여기 ‘관용어’ 그런 거 있잖 아요. 우리가 배우기 때문에 알지만, 새로 들어온 사람들 잘 모 를 수도 있어요."(참여자5)

\section{정보 부족}

자녀의 언어발달 수준을 평가하는 과정에서 겪는 어려운 점으로 는 관련 지식이나 정보의 부족이 보고되었다. 참여자들이 아동의 연령별 언어발달 수준을 어느 정도 파악하고 있는지를 살펴보기 위해 제시한 질문에, 참여자들은 아동의 생활연령보다 횔씬 낮은 수준의 언어발달 수행에도 큰 문제가 없다고 느끼는 모습을 보였 다. 참여자들은 아동의 연령에 따른 적절한 한국어 발달 수준에 대 해서 충분히 알지 못하고, 이에 대한 정보가 부족하다고 언급하였다.

“지금 애기가 아직 만 2살이잖아요. 좀 늦은 애기도 있고, 좀 빨리 할 수 있는 애기도 있잖아요. 그냥 5살 후에 말 못하면 문 제에요. 다섯 살 전에 그냥 말 엄마, 아빠 말 하면 괜찮아요. 이 해할 수 없으면 그게 문제에요. 이해할 수 있으면 상관없어요." (참여자 3)

“(자녀가 3 세인데) 지금, 아빠, 엄마, 싫어, 좋아만 할 수 있어. 다른 말 아직 안돼요."(참여자9)

“그 정도면 괜찮아요."(참여자6)

"우리 애기 나이 맞게 어떻게 공부하는지 그거 나오면 우리 
는 좀알아볼수 있어요. 근데 지금 우리 뮈가 필요한지, 뭔지 몰 라요."(참여자 11)

\section{불충분한 지원 자원}

연구 참여자들은 자녀의 발달을 평가하는 과정에서 겪는 어려 움이 있을 때, 주위에 도움을 받을 만한 인적 자원이 부족한 것이 언어 장벽과 정보 부족으로 인한 문제를 더욱 어렵게 하는 요인이 라고 지적하였다. 참여자들은 한국어에 대한 어려움과 정보의 부 족을 느끼고 있지만, 한결같이 남편이 너무 무관심하거나 바쁘기 때문에 직접적인 도움을 받기가 힘들다고 호소하였다.

"남편은 신경 안쓰고. 저는 만약에 가서 검진하면 전화로 예 약하잖아요. 근데 제가 한국말이 좀 어려워요. 전화하는 거." (참여자 11)

"저는 어쩔 수 없으니까, 남편 해주지 않기 때문에 내가 어쩔 수 없이 해야 되는 거예요."(참여자5)

"보통 남편이 시간 별로 없어요. 그냥 혼자 음식 해요. 응급 실 데리고 가든지, 선생님하고 상담하든지, 어린이집 선생님 통 화하든지. 저 다 혼자 해요. 남편 시간 있으면 그냥 아 남편 다 하라고. 저희 남편은 그냥 남편 없다고 생각하면 돼요. 혼자 해 야 되잖아요. 또 가족마다 생활 다르잖아요, 선생님, 남편 해 달 라고 할 수 없어요. 정말이에요. 할 수 없어요."(참여자 3)

그 외에 다문화가정 어머니들은 취업을 하여 일을 하고 있어 언 어발달검사를 받으러 가기에 충분한 시간이 없다는 것을 지적하기 도 하였고, 아동의 언어발달에 도움이 된다고 생각하는 가정방문 교사나 사설 언어치료실을 이용하기에는 비용 부담이 너무 크다는 이야기도 언급되었다.

“네 그것도 문제예요. 일해서 시간이 없는 사람들 많아요." (참여자 5)

“학습지는 많이 도와줘요. 학습지는 진짜 많이 도와줘요. 그 리고 그 선생님들도 아이들 판단해서 못하는지 아닌지는 판단 해 가지고, 여기 가서 못한다, 여기서 집중한다 그렇게 상담해 줘요. 네 그런데 부담돼요. 비싸서."(참여자 5)

\section{언어발달검사에 대한 개선 요구}

\section{검사 정보 제공 경로의 다양화}

연구 참여자들은 언어발달검사에 대한 관심이 별로 없다는 의견 을 다수 제시하였고, 관심이 있더라도 검사에 대한 정보를 얻기 어 렵다고 호소하였다. 또한 가정으로 영유아발달검사에 대한 안내문 이 오지만 잘 보지 않게 된다는 이야기도 나타났다.
“편지 왔는데 관심 없어요. 그냥이번 달에 전기 얼마나 나온 지. 다른 데는 관심 없어요. 그냥 대충 보고 버렸어요."(참여자 3)

“근데 솔직히 다문화가정(언어발달검사에 대한) 관심이라고 할까? 관심 그렇게 많이 안 가져요. 글쎄, 관심이 별로 없을 거 같아요. 나는 처음 필요 없다고 생각하니까. 그런 생각 들어요." (참여자 5)

"중요하다 생각해요. 근데 어디로 가요? 어디로 가는지 검진 하는지 몰라요."(참여자 11)

만일 자녀의 언어발달에 문제가 있다고 느낄 때 어떤 방법으로 검사를 받는 것이 편하겠냐는 질문에는 다문화센터가 가장 좋을 것 같다는 의견이 많았고, 시간과 장소에 구애받지 않는 모바일을 통한 검사가 있으면 좋겠다는 의견도 제시하였다.

"다문화센터가 제일 편할 것 같아요. 엄마들이. 센터마다 통 역 선생님 계시고 하니까:" (참여자7)

"제 생각에 핸드폰 제일 편할 것 같아요. 요즘 엄마들이 일하 고 있어. 근데 많이 바빠서, 밤에 아침 언제 필요 있으면 바로 찾 아서 할 수 있어 좋을 것 같아. 직접 가면 시간이 없어 못 할 거 같아요. 핸드폰으로 하면 좋을 것 같아요."(참여자9)

"시간이 없는 사람도 있지만, 직접 가서 하면 좋을 것 같아요. 하고 싶은 말도 있고." (참여자 10)

\section{언어적 어려움을 위한 지원}

현행 검사에 대한 개선 요구 중 가장 빈번히 언급된 의견은 언어 적 어려움에 대한 지원 요구로 나타났다. 검사 상황에서 사용되는 전문용어들을 일상적 단어로 쉽게 설명해 주는 것, 구체적이고 쉬 운 예시를 들어 설명해 주는 것이 도움이 될 것이라는 의견이 반복 적으로 언급되었다. 또한 영어와 베트남어 이외의 언어로도 번역을 지원해 주면 좋겠다는 의견이 있었으며, 스마트폰을 이용하여 검사 문항을 바로 번역하여 모국어로 볼 수 있는 기능을 적용하면 좋겠 다는 의견도 제시되었다. 번역 기능과 함께 한글로 적힌 질문을 소 리로 들려주고, 쉽게 말로 설명해 주면 이해하기가 더 쉬울 것이라 는 의견에 참여자들 다수가 동의하였다.

"의료 단어를 쉽게 풀어줘서 애기해 주면 좋겠어요. 왜냐면 솔직히 의료 단어는 힘들어요. 어려워요. 뭐 기본 '설사, 감기' 그 런 거 우리가 알아듣지만, 고급 단어 그런 거 있잖아요. 풀어서 애기해주시거나, 뮈 어떻게 조금이라도 설명해 주시면 좋을 것 같아요. (예시로 제시한 검사지의 문항을 가리키며) '관용어'는 예를 들어서 이렇게 하면 아마 십게 이해할 수 있을 것 같아요." (참여자5) 
"다른 언어도 있잖아요. 조금 쉽게 간단하게 설명해 주면 좋 겠다고 생각해요. 통역 있으면 좋겠다고. 보통 대화하면 관찮은 데, 조금 언어 있잖아요. 좀 저한테 어려워요.” (참여자 3)

"요즘은 베트남, 영어만 잘 나와요. 저 나라는 많이 없어요." (참여자4)

"읽어주고, 이 단어 무슨 뜻인지 설명해 주고, 쉽게 쉽게 하면 아마도움 많이 될 거같아요.” (참여자7)

"왜냐면 한국 단어에는 듣는 거하고 쓰는 거 다르잖아요. 발 음은 이건데 쓸 때는 이거 있잖아요. 말하는 거하고 쓰는 거하 고 다른 단어 그런 게 있잖아요." (참여자5)

"저는 개인적으로 페이스북을 보면 번역하기 누르면 한글 보 이거든요. 자기 핸드폰에 언어 다운 받아서 번역하면 바로 나오 게(하면 좋겠어요)." (참여자7)

"읽으면 쪼끔 알아, 이거, 누가 설명해 주면 좋을 거 같아요. 어려워요. 조금 알아. 이거 읽으면 누가 설명하면 좋아요." (참 여자9)

\section{검사 접근성 및 용이성 향상}

검사의 접근성 및 용이성을 높이기 위한 방법을 묻는 질문에는 검사에 대한 적극적인 홍보의 필요성이 언급되었다. 영유아발달검 사에 대한 정보를 전혀 알지 못하는 참여자도 있었고, 현재 시행되 고 있는 안내문으로는 충분히 정보를 전달받지 못한다는 지적도 나타났다. 또한 다문화가정의 어머니들이 아동의 언어발달에 관심 을 많이 갖지 않으므로, 그 부분에 대한 인식을 개선할 필요성이 있 음도 언급되었다. 그 외, 질문에 답을 한글로 기입하는 것에 어려움 이 있으므로, 간단히 '예/아니오로 응답하기' 및 글이 아닌 '말로 대 답하고 이를 녹음할 수 있는 기능'이 있으면 도움이 될 것이라는 의 견들이 제시되었다.

"근데 솔직히 다문화가정 관심이라고 할까? 이런 거에. 언어 발달. 관심 그렇게 많이 안 가져요. 근데 센터도 안 다니는 사람 들도 있어요. 관심 있는 사람들도 있지만, 안 하는 사람도 있어 요. 그래서 홍보를 잘하면 관심 가질 수 있게끔 해 주면 좋은데. 저도 처음에 이런 거 관심 없었어요. 남편 알아서 하겠지? 그런 생각도 있는 것 같아요. 재미있게 하면 관심을 가질 거 같아요.” (참여자5)

"녹음하면 대부분 엄마 글씨 잘 못 써 가지고, 말할 수는 있 잖아요. 녹음하면 좋을 것 같아요."(참여자 7)

"어떨 때는 쓰는 편해, 어떨 때는 말하는 편해요. 어려운 말, 말할수 있지만 어떻게 쓰는지 몰라요.”(참여자 11)

\section{논의 및 결론}

본 연구에서는 영유아 언어발달 선별검사 개발과 관련한 실제적 요구 분석을 위해 다문화가정 어머니를 대상으로 $\mathrm{FGI}$ 를 실시하였 다. 인터뷰는 연구자의 질문에 기초하여 자유로운 분위기 속에서 두 그룹으로 나뉘어 진행되었고, 인터뷰를 분석하여 도출한 시사 점은 다음과 같다.

첫째, 본 연구에 참여한 다문화가정의 어머니들은 대부분 소아 과를 통한 영유아 건강검진의 하위영역으로 자녀의 영유아 언어발 달 선별검사를 경험하였다. 검사 경험과 관련해서는 검사 시 겪었 던 어려움이 주로 보고되었으며, 중립적이거나 부정적인 경험을 대 체로 보고하였다. 수검 경험이 있는 참여자 중 자발적으로 기관에 의뢰하여 검사를 받은 참여자는 한 명이었고, 나머지 참여자들은 영유아 건강검진 과정을 통해 언어발달 선별검사를 경험한 것으로 나타났다. 다시 말해 대부분의 참여자들이 언어발달검사의 필요성 이나 중요성을 크게 느끼지 않았다고 볼 수 있고, 이러한 점이 경험 에 대한 인상에 영향을 미쳤을 것으로 해석된다.

둘째, 연구 참여자들은 영유아 언어발달 선별검사와 관련하여 언어적 장벽을 가장 공통적인 어려움으로 보고하였으며, 이것이 영 유아 언어발달 선별검사에 대한 다문화가정의 접근을 낮추는 요인 중 하나인 것으로 나타났다. 참여자들이 언어적 소통의 어려움에 대처하는 방법은 남편에게 의지하기, 전문가에게 추가적인 도움을 요청하기 정도였고, 남편이 바빠서 직접적인 도움을 받기 어렵다는 제약들도 보고되었다. 언어적 어려움을 위한 지원으로는 번역 서비 스에 대한 요구가 높았고, 용어에 대한 자세한 설명과 예시가 제시 되면 도움이 될 것이라고 제안했다. 영유아 건강검진의 경우 중국 어와 베트남어로 번역된 서식은 제공되고 있지만, 그 외의 언어 서 비스는 제공되고 있지 않다. 연구에 참여한 캄보디아 출신의 어머 니는 캄보디아어 번역 서비스는 제공되지 않아 검사에 어려움이 있 었다고 토로하기도 하였다. 따라서 다양한 출신 배경을 고려한 세 분화된 언어적 지원이 필요할 것이다.

셋째, 다문화가정을 대상으로 영유아 언어발달 정보 및 검사 정 보에 대한 접근성을 높이려는 노력이 필요하다. 먼저 아동의 언어발 달 수준을 조기에 선별하기 위해서는 부모의 지속적인 관심을 통 한 평가 혹은 평가의뢰가 중요한데, 연구 참여자들은 언어발달 관 련 정보가 부족함을 느끼며, 어디에서 정보를 얻을 수 있는지 잘 모 르겠다고 보고하였다. 이러한 정보 부족에 대한 어려움은 언어영역 뿐만 아니라 자녀양육 및 교육과 관련하여서도 일관되게 보고되고 있는 어려움이다(Bae \& Bong, 2012; Oh, 2011). 실제로 본 연구의 인터뷰에서 연구 참여자들이 자녀의 연령에 비해 횔씬 더 낮은 수 
준의 언어발달을 기대하고 있다는 점이 나타났다. 아동의 생활연령 에 따라 어느 정도의 한국어 이해 및 표현을 기대해야 하는지에 대 한 기초적인 지식이 부족하고, 이와 함께 어머니의 서툰 한국어가 자녀의 언어발달에 대한 민감도를 낮추는 요인으로 작용했다고 추 측할 수 있다. 더불어 다문화가정의 아동들이 언어검사에 쉽게 접 근할 수 있도록 하기 위해서는 검사 정보 제공의 경로를 다양화하 거나, 모바일 기기를 활용해 물리적 접근성을 높이면서 번역이나 녹음과 같은 여러 기능을 제공함으로써 검사 용이성을 높이는 방 법 등이 제안되었다.

본 연구에서는 다문화가정 어머니들을 대상으로 FGI를 실시하 여 다문화가정 아동의 언어발달 선별검사 개발을 위한 요구를 분 석하고자 하였다. 후속연구에서는 전문가 집단을 대상으로 좀 더 구체적인 논의를 펼칠 수 있을 것이다. 더불어 검사의 접근성 및 용 이성과 관련하여 논의에서 언급된 모바일 활용에 대한 키워드도 중요하게 검토할 수 있을 것이며, 이 논의는 언어 중재 및 평가도구 로써 모바일 기기 활용의 탐색 가능성을 긍정적으로 제시한 선행 연구(Yim, Kim, Park, Cheon, \& Lee, 2014)와 같이 검사에 대한 접 근 장벽을 완화할 수 있는 평가방법 및 도구에 대한 필요성을 환기 시킨다. 그리고 추후 영유아 언어발달 선별검사 개발 과정에서는 이와 같은 요구 분석을 통해 대상 집단의 특성에 기초한 실질적인 요구를 반영할 수 있을 것이다.

국내 다문화가정이 꾸준히 증가함에 따라 다문화가정의 사회적 통합을 위한 여러 가지 제도적, 교육적인 지원들이 마련되고 있으 며, 이를 뒷받침하기 위한 연구가 여러 학문 분야에 걸쳐 이루어지 고 있다. 이러한 사회적 배경에서 다문화가정 아동들의 언어 문제 를 조기 선별하는 것과 관련한 본 연구는 다문화가정 아동들의 언 어발달 문제의 심화를 예방하고, 이를 통해 학령기 이후의 학업 및 학교 적응에 긍정적인 영향을 미침으로써 다문화가정의 사회적 통 합을 위한 과정에 밑거름이 되고자 한다.

\section{REFERENCES}

Ahn, S., \& Shin, Y. (2008). A compare study of multi-cultural background children's and low-income children's phonological awareness ability. Journal of Speech \& Hearing Disorders, 17(4), 81-94.

Bae, J. H., \& Bong, J. Y. (2012). Mothers' experiences of child rearing in multicultural families. Journal of Early Childhood Education, 32(2), 383-405.

Bogdan, R. C., \& Biklen, S. K. (2007). Qualitative research for education: an introduction to theory and methods (5th ed.). Boston, MA: Allyn \& Bacon.

Brescia, W. F., Swartz, J., Pearman, C., Balkin, R., \& Williams, D. (2004). Peer teaching in web based threaded discussions. Journal of Interactive Online Learning, 3(2), 1-22.

Cho, S. N., Lee H. J., Joo, Y. J., \& Kim, N. Y. (2011). Qualitative research design « practice. Seoul: Green Publications.

Hwang, S. S., \& Jeong, O. R. (2008). A study on language characteristics correlation of the children in culturally diverse family environments. Journal of Speech-Language \& Hearing Disorders, 17(1), 81-102.

Kim, Y. K. (2015). The family life adjustment of children from multicultural families and policy implications. Health and Welfare Policy Forum, 226, 75-89.

Kim, Y. R., Kim, Y. T., \& Lee, E. J. (2007). Literature review regarding validity of the dynamic assessment applied in lexical learning ability measures for bilingual children. Journal of Speech \& Hearing Disorders, 16(3), 59-77.

Kim, Y. T., Kim, K. H., Yoon, H. R., \& Kim, H. S. (2003). Sequenced Language Scale for Infants (SELSI). Seoul: Special Education Publishing.

Kwon, S. H. (2009). The actual conditions of Korean use by multicultural students. Korean Language Education Research, 36, 195-228.

Kwon, S. J. (2006). Comparison of characteristics in generative naming for children of multi-culture family and children of ordinary family (Master's thesis). Myongji University, Seoul, Korea.

Lee, S. J., Shin, J. C., Kim, H. H., \& Kim, H. S. (2008). A study on expressive vocabulary ability in multicultural family children: based on K-BNT-C. Journal of Speech-Language \& Hearing Disorders, 17(3), 95-115.

Ministry of Health and Welfare. (2010). Get a medical checkup for children from multicultural families in mother's language. http://www.mohw.go.kr/ react/al/sal0301vw.jsp?PAR_MENU_ID=04\&MENU_ID=0403\&page= $18 \& C O N T \_S E Q=237312 \& S E A R C H K E Y=C O N T E N T \& S E A R C H V A L U$ $\mathrm{E}=\% \mathrm{EA} \% \mathrm{~B} 1 \% \mathrm{~B} 4 \% \mathrm{EA} \% \mathrm{~B} 0 \% 95 \% \mathrm{EA} \% \mathrm{~B} 2 \% 80 \% \mathrm{EC} \% \mathrm{A7} \% 84$

Ministry of Interior and Safety. (2018). 2017 status of foreign residents in local governments. https://www.mois.go.kr/frt/bbs/type001/commonSelectBoardArticle.do;jsessionid=e3aWiS0pADQnoxaI68Rze0wk.node40?bbsI d=BBSMSTR_000000000014\&nttId=66841

Oh, M. S. (2011). Realities and challenges of education for children of multicultural families in Korea: preliminary results from interviews of six multicultural families. Multicultural Education Studies, 4(1), 43-77.

Oh, S. J., Kim, Y. T., \& Kim, Y. R. (2009). Preliminary study on language characteristics and related family factors in children from multicultural family. Special Education Research, 8(1), 137-161.

Olswang, L. B., Rodriguez, B., \& Timler, G. (1998). Recommending intervention for toddlers with specific language learning difficulties: we may not 
have all the answers, but we know a lot. American Journal of Speech-Language Pathology, 7(1), 23-32.

Park, S. H. (2009). A longitudinal study of articulation production of children from culturally diverse family environments. Journal of Speech-Language \& Hearing Disorders, 18(1), 89-97.

Park, S. H., \& Jung, M. S. (2012). A qualitative study on speech and language intervention in children from multicultural families. Korean Journal of Communication \& Disorders, 17(1), 47-65.

Pence, K. L., \& Justice, L. M. (2008). Language development from theory to practice. Upper Saddle River, NJ: Pearson.

Schwandt, T. A. (2014). The Sage dictionary of qualitative inquiry. Thousand Oaks, CA: Sage Publications Inc.

Strauss, A., \& Corbin, J. M. (1990). Basics of qualitative research: grounded theory procedures and techniques. Thousand Oaks, CA: Sage Publications
Inc.

Suh, H. (2007). Multicultural family and Korean language education. Journal of Human Studies, 12, 57-92.

Yang, S. O., \& Hwang, B. M. (2009). A comparative study of the phonological awareness ability of preschool children from multi-cultural families and single-culture families. Journal of Speech \& Hearing Disorders, 18(1), 3757.

Yim, D., Kim, S. Y., Park, W., Cheon, S., \& Lee, Y. J. (2014). Analysis on needs based survey of parents and speech-language pathologists for smartphone programs. Communication Sciences \& Disorders, 19(4), 486-500.

Yoo, H. J., Kim, H. H., Kim, W. S., \& Shin, J. C. (2008). Articulation ability and phonological process in multicultural family children. Speech Sciences, 15(3), 133-144. 


\section{국문초록}

\section{영유아 언어발달 선별검사 개발을 위한 다문화가정 어머니의 요구 분석: 포커스 그룹 인터뷰를 중심으로 최은정 $\cdot$ 정상임 ${ }^{2}$ 임동선 ${ }^{1}$ 김영태 ${ }^{1}$ \\ ${ }^{1}$ 이화여자대학교 언어병리학과, ${ }^{2}$ 우송대학교 언어치료청각재활학과}

배경 및 목적: 다문화 아동들은 언어발달의 다양한 영역에서 어려움을 겪을 수 있으므로 다문화 아동의 언어발달 수준을 조기에 선별 하는 것이 중요하다. 이를 위해서는 다문화 집단의 특수성을 반영한 언어발달 선별검사가 고안되어야 하는데, 양적 연구만을 통해서는 다문화가정 대상자들의 실질적 요구를 반영하기 어렵다는 점에서 질적 연구의 필요성이 있다. 이러한 필요성에 따라 본 연구에서는 영 유아 언어발달 선별검사에 대한 다문화가정 어머니의 인식과 요구를 분석하고자 하였다. 방법: 본 연구에 참여한 다문화가정 어머니 11 명을 두 그룹으로 나누어 포커스 그룹 인터뷰(FGI)를 진행하고, 그 내용을 분석하였다. 결과: 인터뷰 분석 결과, 3 개의 대주제(언어발달 수검 경험, 자녀 언어발달 평가의 어려움, 언어발달검사에 대한 개선 요구)와 9 개의 하위 주제로 분석되었다. 논의 및 결론: 다문화 아동 의 언어발달 선별검사 개발을 위해서는 언어적 장벽, 언어발달 정보 및 검사 정보의 접근성에 대한 고려가 필요할 것이다.

핵심어: 다문화가정, 영유아 언어발달 선별검사, 질적 연구, 요구 분석

본 논문은 2018년 대한민국 교육부와한국연구재단의 지원을 받아 수행된 연구임(No. NRF-2018S1A3A2075274).

\section{참고문헌}

권수진(2006). 다문화가정아동과 일반가정아동의 생성 이름대기 특성 비교. 명지대학교 대학원 석사학위논문.

권순희(2009). 다문화 가정 자녀의 국어 사용 실태. 국어교육학연구, 36, 195-228.

김영란, 김영태, 이은주(2007). 이중언어아동의 어휘학습능력 측정에 적용된 역동적 평가에 대한 타당성 고찰: 1990년 이후의 문헌을 중심으로. 언어

치료연구, 16(3), 59-77.

김영태, 김경희, 윤혜련, 김화수(2003). 영유아 언어발달검사(SELSI). 서울: 도서출판 특수교육.

김유경(2015). 다문화가족아동의 가족생활 적응실태와 정책과제. 보건복지포럼, 226, 75-89.

류현주, 김향희, 김화수, 신지철(2008). 다문화가정 아동의 조음능력 및 음운변동 특성, 음성과학 15(3), 133-144,

박상희(2009). 다문화가정 아동의 조음산출에 관한 종단적 연구. 언어치료연구, 18(1), 89-97.

박소현, 정명심(2012). 다문화가정 아동의 언어치료에 대한 질적 연구. 언어청각장애연구, 17(1), 47-65.

배지희, 봉진영(2012). 다문화 가정 어머니의 자녀양육 경험에 대한 탐구. 유아교육연구, 32(3), 383-405.

보건복지부(2010). 다문화가족 영유아 건강검진, 어머니 나랏말로 검진받아요. http://www.mohw.go.kr/react/al/sal0301vw.jsp?PAR_MENU_

ID $=04 \&$ MENU_ID $=0403 \&$ page $=18 \& C O N T \_S E Q=237312 \&$ SEARCHKEY $=$ CONTENT $\&$ SEARCHVALUE $=\% E A \% B 1 \% B 4 \% E A \% B 0 \% 9$ $5 \% \mathrm{EA} \% \mathrm{~B} 2 \% 80 \% \mathrm{EC} \% \mathrm{~A} 7 \% 84$

서혁(2007). 다문화 가정 현황 및 한국어 교육 지원 방안. 인간연구, 12, 57-92.

안성우, 신영주(2008). 저소득층 일반아동과 다문화가정 아동의 음운인식능력 비교연구. 언어치료 연구, 17(4), 81-94.

양성오, 황보명(2009). 취학 전 다문화가정 아동과 일반가정 아동의 음운인식능력 비교 연구. 언어치료연구, 18(1), 37-56.

오만석(2011). 다문화가정 자녀교육의 현실과 과제: 여섯 가정을 중심으로. 다문화교육연구, 4(1), 43-77.

오소정, 김영태, 김영란(2009). 서울 및 경기지역 다문화가정 아동의 언어특성과 관련변인에 대한 기초 연구. 특수교육, 8(1), 137-161.

이수정, 신지철, 김향희, 김화수(2008). 다문화가정 아동의 표현어휘능력 연구: K-BNT를 중심으로. 언어치료연구, 17(3), 95-115.

임동선, 김신영, 박원정, 천성혜, 이여진(2014). 스마트폰 프로그램 개발을 위한 의사소통장애 아동 부모 및 전문가 요구 분석. Communication Sci-

ences \& Disorders, 19(4), 486-500. 
조성남, 이현주, 주영주, 김나영(2011). 질적연구방법과 실제. 서울: 도서출판 그린.

행정안전부(2018). 2017년 지방자치단체 외국인주민현황. https://www.mois.go.kr/frt/bbs/type001/commonSelectBoardArticle.do;jsessionid=e3a WiS0pADQnoxaI68Rze0wk.node40?bbsId = BBSMSTR_000000000014\&nttId = 66841

황상심, 정옥란(2008). 다문화가정 아동들의 언어발달과 관련변인 상관연구. 언어치료연구, 17(1), 81-102.

\section{ORCID}

최은정(https://orcid.org/0000-0002-7205-250X); 정상임(https://orcid.org/0000-0003-1389-0404);

임동선(https://orcid.org/0000-0001-8254-9504); 김영태(https://orcid.org/0000-0003-1738-6862) 